\title{
Exercise therapy in Type 2 diabetes
}

\author{
Stephan F. E. Praet · Luc J. C. van Loon
}

Received: 2 December 2008/ Accepted: 7 May 2009/Published online: 29 May 2009

(c) The Author(s) 2009. This article is published with open access at Springerlink.com

\begin{abstract}
Structured exercise is considered an important cornerstone to achieve good glycemic control and improve cardiovascular risk profile in Type 2 diabetes. Current clinical guidelines acknowledge the therapeutic strength of exercise intervention. This paper reviews the wide pathophysiological problems associated with Type 2 diabetes and discusses the benefits of exercise therapy on phenotype characteristics, glycemic control and cardiovascular risk profile in Type 2 diabetes patients. Based on the currently available literature, it is concluded that Type 2 diabetes patients should be stimulated to participate in specifically designed exercise intervention programs. More attention should be paid to cardiovascular and musculoskeletal deconditioning as well as motivational factors to improve long-term treatment adherence and clinical efficacy. More clinical research is warranted to establish the efficacy of exercise intervention in a more differentiated approach for Type 2 diabetes subpopulations within different stages of the disease and various levels of co-morbidity.
\end{abstract}

Keywords Exercise prescription · Pathophysiology · Type 2 diabetes - Treatment adherence - Complications . Safety

\footnotetext{
S. F. E. Praet $(\bowtie)$

Department of Rehabilitation Medicine,

Erasmus University Medical Center,

P.O.Box 2040, 3000 CA Rotterdam, The Netherlands

e-mail: s.praet@erasmusmc.nl

\section{J. C. van Loon}

Department of Human Movement Sciences, Faculty of Health Medicine and Life Sciences, Maastricht University Medical Center+, Maastricht, The Netherlands
}

\section{Type 2 diabetes: a modern, but not modest, health threat}

Already in the first century, the ancient Greek physician Aretaeus of Cappadocia described the term diabetes (diabainein) as '....a wonderful affection, not very frequent among men...' [1]. However, it was not until 1675 that Thomas Willis, an English physician, added the word mellitus, as a reference to the sweet taste of a diabetes patient's urine. Whether this condition referred to Type 1 (autoimmune disease) or Type 2 (relative insulin deficiency) diabetes mellitus is unknown. However, it lasted another 200 years before the French physician Lanceraux made the distinction between diabetes in lean and obese men: diabete gras and diabete maigre [2]. In the $1930 \mathrm{~s}$, the diabetologist Joslin c.s. noted that the incidence of diabetes in lean individuals was relatively constant in each decade of life, while diabetes in the obese was related to age [3]. Already in those days he attributed the increasing prevalence of diabetes in the $1930 \mathrm{~s}$ to increasing obesity [3].

The sharp rise in Type 2 diabetes prevalence during the second half of the twentieth century first occurred in developing countries, parallel to the rapid socio-economic development and dramatic changes in lifestyle in these countries [4]. In traditionally more affluent societies, the prevalence of Type 2 diabetes showed a clear rise in the early $1990 \mathrm{~s}[5,6]$, almost parallel to the increase in the prevalence of obesity [7]. Although genome-wide association studies have revealed that certain single nucleotide polymorphisms (SNPs) related to beta-cell function predispose to the development of Type 2 diabetes [8-11], clinical characteristics such as obesity and lack of physical activity are regarded as the most important risk factors, both independently associated with diabetes and diabetesrelated co-morbidities [12-14]. 
According to the International Diabetes Federation (IDF), the disease now affects 246 million people worldwide and is expected to affect some 380 million by 2025 , representing as much as $7.1 \%$ of the global adult population [15]. As such, the associated health burden in terms of cardiovascular disease, kidney failure, blindness, amputations and premature death will increase progressively, unless more effective primary and secondary pharmaceutical and/or lifestyle interventional strategies become more widely available.

\section{Metabolic disturbances associated with Type 2 diabetes}

\section{Hyperglycemia in the insulin-resistant state}

The main feature of Type 2 diabetes is formed by the relative resistance to peripheral insulin action, resulting in impaired glycemic control. According to WHO criteria, someone is considered to have Type 2 diabetes if fasting plasma glucose levels are equal or above $7.0 \mathrm{mmol} / \mathrm{l}$ or if $2 \mathrm{~h}$ following an $75 \mathrm{~g}$ oral glucose tolerance test (OGTT) plasma glucose concentration rises $\geq 11.1 \mathrm{mmol} / 1$ [16]. Although still subject of intense debate, these diagnostic cut-off points have been based on epidemiological studies that have examined the risk of developing retinopathy over a range of plasma glucose levels [17]. However, even in 'high-risk' obese subjects without blood glucose abnormalities during an OGTT, real-life hyperglycemia was already detectable for almost $14 \%$ throughout the day [18]. This indicates that even in the absence of formal intermediate hyperglycemia, as defined by the IDF/World Health Organisation (WHO) [17], so-called post-prandial hyperglycemic spikes are probably an early feature of the insulin-resistant state. The difficulties to manage this post-prandial hyperglycemia were exemplified in two of our most recent continuous glucose monitoring studies in Type 2 diabetes patients [19, 20]. In these studies, we show that hyperglycemia is experienced for as much as 8-13 h/day under strict dietary standardization, but otherwise free-living conditions. A strong correlation was observed between the prevalence of hyperglycemia and $\mathrm{HbA}_{1 \mathrm{c}}$ content in the Type 2 diabetes patients, but even patients with apparent acceptable glycemic control $\left(\mathrm{HbA}_{1 \mathrm{c}} \leq 7.0 \%\right)$ were still experiencing hyperglycemia for $11 \pm 0.9 \mathrm{~h}$ throughout the day [20]. It has been suggested that these hyperglycemic blood glucose excursions may contribute to the development of macro- and/or microvascular complications in prediabetic states [21, 22]. However, many different pathophysiological pathways may be simultaneously activated (see below). Therefore, its separate contribution to macro- or microvascular complications is currently unknown.
Hyperglycemia and beta-cell failure

The pathophysiological basis for aforementioned postprandial hyperglycemic spikes lies in a disturbed firstphase insulin response of the pancreatic beta-cell, which normally suppresses endogenous glucose production. Subsequently, beta-cell function further deteriorates and endogenous insulin production is insufficient to fully compensate for the peripheral insulin insensitivity in muscle, liver and/or fat cells [23]. Although the susceptibility for a glucose-stimulated insulin secretory defect has a genetic origin [24], it only becomes apparent in the context of peripheral insulin resistance $[25,26]$. Once the beta-cell fails, post-prandial hyperglycemia may induce large amounts of reactive oxygen species (ROS) that can cause further damage to cellular components of insulin production and induce apoptosis in beta-cells [27]. In addition, lipotoxicity [28] and possibly also amyloid deposits [29] may contribute to further deterioration of beta-cell function. Certain drugs, such as sulfonylurea (SU) derivatives, are still widely applied to stimulate glucose-dependent insulin release. Although these drugs temporarily improve glucose homeostasis, they do not restore beta-cell function and may accelerate loss of long-term glycemic control [30]. In a quest to improve long-term diabetes outcome, a whole new line of drugs has become available that try to mimic the release of specific gut hormones [31]. These incretin mimicking drugs have been shown to improve islet-cell function, and both fasting and post-prandial glycemic control [32-36]. Nevertheless, more long-term efficacy of incretin mimicking drugs should be awaited before their clinical value as a mono- or add-on therapy can be established [37-39]. Besides medication, dietary measures such as slowly digestible carbohydrates [40] and the application of amino acid induced insulin secretion [41-43] and/or high protein diets [44] can modulate post-prandial hyperglycemia as well. As such, structured lifestyle interventions combined with metformin remain the first treatment of choice. If oral dose adjustment is not sufficient to meet therapeutic targets, early exogenous insulin therapy should be initiated [45].

\section{Obesity and insulin resistance}

Over the past three decades, the etiology of insulin resistance and beta-cell dysfunction has been subject to intense study [23, 46]. Obesity, as a result of inactivity in combination with overeating, plays a key role in the development of pancreatic beta-cell dysfunction as well as insulin resistance. Several mechanisms mediating this interaction have been identified. It is now well established that a number of circulating hormones, cytokines, and metabolic fuels, such as non-esterified fatty acids (NEFAs), are being 
released by adipose tissue and can modulate insulin action. An increased mass of stored triglyceride, especially in visceral or deep subcutaneous adipose depots, leads to large adipocytes that are themselves resistant to the ability of insulin to suppress lipolysis. This results in increased release and circulating NEFA and glycerol levels. Both aggravate insulin resistance in skeletal muscle $[47,48]$ and the liver $[49,50]$.

\section{Adipokines and chronic inflammation}

Besides increased concentrations of NEFA, expanded visceral adipose tissue also releases pro-inflammatory cytokines [e.g., tumor necrosis factor $\alpha$ (TNF- $\alpha$ ), interleukin-6 (IL-6), monocyte chemoattractant protein-1 (MCP-1)]. Pathways regulating suppression of cytokine signaling proteins [51] and inducible nitric oxide synthase [52] may be involved in mediating cytokine-induced insulin resistance. Secretion of these cytokines, particularly MCP-1 by adipocytes, endothelial cells and monocytes, increases macrophage recruitment and subsequently amplifies cytokine-induced insulin resistance in a feed forward manner [53]. TNF- $\alpha$ and IL- 6 act through classical receptor-mediated processes, resulting in upregulation of potential mediators of systemic inflammation that can lead to insulin resistance.

More recently, a new adipokine, named retinol binding protein-4, has been discovered that is directly linked to the level of obesity-induced insulin resistance, both in crosssectional [54, 55] and longitudinal studies [54, 56-58]. Another adipokine, subject to intense study, is adiponectin. Low adiponectin levels have been correlated with visceral obesity and whole-body insulin sensitivity [59]. This fat cell hormone acts as an insulin sensitizer, inhibiting triglyceride formation in liver and stimulating fatty acid oxidation in muscle in an AMP-activated protein kinase (AMPK) and peroxisome proliferators activated receptor alpha (PPAR- $\alpha$ )-dependent way [60]. Despite their apparent importance in the insulin resistance syndrome, aforementioned adipokines are just examples of a family of adipocyte-derived factors that modulate insulin resistance and systemic inflammation. Besides new adipokines, also certain myokines now appear to affect insulin sensitivity and inflammatory responses [61]. As such, the list of insulin (de)sensitizing proteins and cytokines is still far from complete.

Ectopic fat storage causes insulin resistance in muscle and liver

In the context of a low habitual physical activity level and low oxidative capacity, excess intramyocellular lipid (IMCL) storage has been associated with skeletal muscle insulin resistance [62]. In accordance, intervention studies indicate that insulin sensitivity can change independently of IMCL contents [63-68]. Indeed, not IMCL content itself, but rather the peroxidation of inactive pools of IMCL and intra-cellular fatty acids may explain the apparent correlation between IMCL content and insulin resistance [69]. In addition, intra-cellular lipid metabolites such as diacylglycerol (DAG), long chain fatty-acyl $\mathrm{CoA}$ and ceramides have been shown to interfere with the insulin signaling pathway [70]. These metabolites activate a protein kinase leading to the phosphorylation of serine/threonine sites on the insulin receptor substrate 1 , subsequently hampering glucose transport activity and insulin-stimulated myocellular glucose uptake [71].

Ectopic fat storage in hepatocytes, so-called intrahepatic lipids (IHL), has also been related to the development of hepatic insulin resistance [72] and hepatic inflammation, initiating non-alcoholic fatty liver disease [73]. In rodents, 3 days of a high-fat diet induces hepatic insulin resistance, while no significant changes in fat content in muscle or visceral tissue could be detected [74]. Experimental research now suggests that hepatic insulin resistance arises from DAG-induced activation of protein kinase $\mathrm{C} \varepsilon$, which directly binds to and inhibits insulin receptor tyrosine kinase activity [75]. As such, fat-induced hepatic insulin resistance and hepatic inflammation are considered important etiological factors in the development of systemic insulin resistance.

Glucolipotoxicity and long-term complications in Type 2 diabetes

Besides inhibiting intra-cellular insulin signaling, aforementioned metabolic disturbances in glucose and fat metabolism increase the formation of Amadori-glycated proteins and advanced glycation end-products (AGE) impairs receptor function for AGE (RAGE) and increases exposure to ROS in almost any organ system [76-78]. Chronic exposure to Amadori products, AGE and ROS, so-called glucolipotoxicity, can cause vasculopathy [76], glomerulopathy $[79,80]$ and potentially also induce nerve cell damage [81]. In accordance, hyperglycemia-induced AGE and ROS formation provide a unifying model for the high incidence of microvascular disease, retinopathy, nephropathy [80, 82], and possibly also neuropathy [83] prevalent in long-term Type 2 diabetes [84]. In accordance, certain pharmaceutical [85, 86], nutritional [81] and/or exercise interventions [87-89] that modulate AGE, RAGE and/or ROS formation have been reported to improve insulin sensitivity in experimental rodent models. In humans, both structured exercise and alpha lipoic acid have been suggested to reduce neuropathic symptoms [90, 91]. However, it is unknown whether such a combined and 
long-term approach can modulate glucolipotoxicity and prevent diabetes-related complications [92].

Reduced oxidative capacity and mitochondrial function in insulin-resistant states

It has been well established that most patients with Type 2 diabetes have a significantly lower oxidative capacity $\left(\mathrm{VO}_{2 \text { peak }}\right)$ than age-matched controls [93-95]. Whether this lower oxygen uptake capacity is attributed to a low habitual physical activity level, reduced mitochondrial content or an intrinsic mitochondrial defect is a topic of intense debate [96-109]. Recent experimental evidence indicates that mitochondrial respiration is not abnormal when normalized for mitochondrial content [104, 110], which implies that low habitual physical activity level and/or cardiovascular dysfunction may explain the generally deconditioned state in the Type 2 diabetes patient [97, 106]. Although the debate will probably continue whether the lower oxidative capacity represents either cause or consequence [97, 111], future exercise studies should be aimed at answering the question whether a substantial long-term increase in physical activity level by implementing a well-structured exercise intervention program can reverse the deconditioned state of Type 2 diabetes patients and improve the metabolic profile.

Hyperinsulinemia, autonomic dysregulation and cardiovascular disease

Above-mentioned metabolic disturbances in oxidative capacity, glucose homeostasis and fat metabolism not only affect systemic insulin resistance, but also appear to influence long-term energy homeostasis [112]. Animal studies indicate that long-term energy balance is coordinated through the combined action of insulin and leptin in the brain [113]. Interestingly, these studies have suggested that insulin action in certain hypothalamic centers reduces food intake while increasing sympathetic nervous system (SNS) outflow to brown adipose tissue to produce heat from fatty acid oxidation as a mechanism to increase energy expenditure [113]. As such, these chronically elevated insulin [114, 115] and leptin concentrations [116] further contribute to obesity-associated hypertension through activation of the SNS and release of catecholamines in the basal state [117]. Indeed, early-stage insulin resistance appears to cause sympathovagal imbalance in normoglycemic, insulin-resistant offspring of Type 2 diabetes patients [118]. Also in more advanced insulin-resistant states, aforementioned increases in sympathetic tone have been associated with changes in cardiac and vascular function that lead to hypertension, left ventricular dysfunction and/or cardiac autonomic neuropathy [119]. Such changes set the stage for arrhythmia, silent infarction and sudden death $[120,121]$. Because potentiation of atherogenesis and cardiac dysfunction occurs in the presence of early diabetic symptoms as well as in the established disease [122, 123], early implementation of strategies to reduce cardiovascular risk factors and to attenuate diabetes progression may help to improve long-term outcomes for at-risk individuals. Such interventions may include wellestablished pharmaceutical treatments for hypertension and dyslipidemia, dietary modulation and/or energy restriction, weight loss, and exercise intervention [121].

\section{Exercise as opposed to pharmaceutical therapy in Type 2 Diabetes}

Over the past 5 years, both lipid lowering therapy [124, 125] and blood pressure lowering therapies [126, 127] have been proven effective to improve cardiovascular outcome in Type 2 diabetes patients. The effectiveness of these drugs may explain why the additive benefits of intensive glycemic control are more difficult to demonstrate, even in large and long-term clinical trials such as ACCORD, ADVANCE and VADT [128]. Nevertheless, much effort is currently put into the discovery of novel pharmacological solutions that may further improve metabolic control and prevent diabetesrelated co-morbidities. Although the combination of intense blood pressure and blood glucose lowering therapy has been shown to reduce (microvascular) complications [129-131], stringent application of multiple blood glucose lowering drugs does not necessarily result in a further reduction of macrovascular events [130, 132-135]. Especially, in more advanced Type 2 diabetes, more intensive blood glucose lowering strategies may have counter-balancing consequences for cardiovascular disease, such as hypoglycemia, weight gain, or other metabolic changes [128]. Although results of long-term intervention studies are underway, the current increase in Type 2 diabetes incidence and concomitant cardiovascular co-morbidities may benefit more from therapeutic strategies entailing structured exercise interventions with [136-138] or without [137, 139, 140] dietary modulation and/or oral blood glucose lowering medication [136, 141, 142].

Does exercise reverse chronic inflammation?

In insulin-resistant populations, several adipokines, such as leptin and adiponectin, as well as muscle contractioninduced factors, so-called myokines (i.e., IL-6), have been shown to modulate insulin resistance and inflammatory status [143]. Although there is consensus that weight loss is associated with an increase in adiponectin and decreased levels of leptin, TNF- $\alpha$ and high sensitivity C-reactive 
protein (hsCRP) [144, 145], studies on the medium-term effects of exercise without concomitant weight loss are limited and produce somewhat inconsistent results [146-148]. Nevertheless, the finding in longitudinal studies that regular exercise training induces a reduction in hsCRP indicates that physical activity may help to suppress systemic low-grade inflammation [149-151]. An experimental study using endotoxin-induced chronic inflammation showed that physical exercise directly inhibits endotoxininduced TNF- $\alpha$ production in humans, most likely through IL-6 release from exercising muscle [152]. Clearly, more long-term intervention studies are warranted to see to what extent the proposed anti-inflammatory effect of exercise training modulates peripheral insulin sensitivity in Type 2 diabetes patients.

Exercise as an antihypertensive agent

Besides improving glycemic control, a recent meta-analysis showed that structured exercise intervention studies in noninsulin-dependent Type 2 diabetes patients reduce systolic blood pressure with $-4.16 \mathrm{mmHg}(95 \% \mathrm{CI}-9.46$ to 1.14$)$ [153]. Such reductions in mean arterial blood pressure are clinically relevant and are similar to the effects of add-on blood pressure lowering therapy using a combination of an ACE inhibitor and thiazide diuretic [126]. Although both resistance- and endurance-type exercise seem to reduce mean arterial blood pressure to a similar extent in Type 2 diabetes populations [154], further research is needed to explore their separate contribution and way of action in different insulin-resistant (sub)populations.

Does exercise therapy improve lipid metabolism?

Although fasting blood lipid profiles in Type 2 diabetes populations have been shown to improve following longterm exercise interventions with [136, 137, 155] or without dietary restriction $[142,156]$, recent exercise intervention studies in Type 2 diabetes patients showed few to no additional benefits on top of lipid lowering agents [146, 157]. The latter may be related to the lack of a simultaneously diet-induced weight loss [158], a compensatory decline in daily physical activity level [159] or the fact that in most Type 2 diabetes populations baseline total-cholesterol, LDL-cholesterol and triglycerides levels were already 15-35\% lower in comparison with aforementioned 'exercise-only' intervention studies [142, 156]. Nevertheless, in accordance with earlier reports (for references see [160]), detailed body composition analyses using dual energy X-ray absorptiometry (DEXA) and MRI revealed that, despite an unaltered body weight, 5-6 months of combined endurance and resistance type of exercise training is able to induce regional changes in fat and lean muscle mass in obese Type 2 diabetes patients [146, 157]. Indeed, several lines of research [68, 161-163] now indicate that exercise interventions of sufficient volume and intensity may also modulate post-prandial lipid handling. Interestingly, higher levels of habitual physical activity were reported to be strongly associated with reduced IHL content [164], while intervention studies using dietary or exercise intervention report somewhat contrasting results $[165,166]$, supporting the idea that nutritional modulation may be more effective in reducing IHL content. Future studies should aim to unravel the mechanisms of action and modulating effects of different modes of exercise training on postabsorptive and post-prandial lipid handling in Type 2 diabetes patients [167]. Ideally, dietary intake and hormonal responses should be monitored to differentiate between the impact of isocaloric exercise bouts of different volumes and intensities on both post-prandial glycemia and lipidemia.

\section{Exercise prescription in Type 2 diabetes}

Current guidelines from the American Diabetes Association (ADA), the European Association for the Study of Diabetes (EASD) or the American College of Physicians (ACP) all acknowledge the therapeutic strength of exercise intervention [45, 168-170]. The ADA states that 'to improve glycemic control, assist with weight maintenance, and reduce risk of CVD, at least $150 \mathrm{~min} /$ week of moderate-intensity aerobic physical activity is recommended and/ or at least $90 \mathrm{~min} /$ week of vigorous aerobic exercise, ... distributed over at least 3 days/week and with no more than 2 consecutive days without physical activity.' Since 2006, the ADA guidelines explicitly mention and recognize that 'in the absence of contraindications, people with Type 2 diabetes should be encouraged to perform resistance exercise 3 times a week, targeting all major muscle groups, progressing to 3 sets of $8-10$ repetitions at a weight that can not be lifted more than 8-10 times' [169]. However, these clinical guidelines generally do not include detailed information on the preferred type and intensity of exercise that should be applied to maximize the benefits of exercise for different subgroups of Type 2 diabetes patients and further research is needed.

Acute versus more longer term exercise responses

Both a single bout of endurance- [171] and resistance-type exercise [172, 173] have been shown to improve wholebody insulin sensitivity and/or oral glucose tolerance. Therefore, both types of exercise are of therapeutic use in an insulin-resistant state [154]. The acute effects of exercise on skeletal muscle insulin sensitivity are attributed to the prolonged activation of the skeletal muscle glucose 
transporter system [174, 175], depletion of liver and muscle glycogen stores [174, 176-178], and/or increased skeletal muscle blood flow following the cessation of exercise [179]. The glucoregulatory benefits of either type of exercise training are represented by the sum of the effects of each successive bout of exercise [178]. In addition, more prolonged exercise training is accompanied by a more structural adaptive response. For instance, endurance training may upregulate mitochondrial enzyme activity in skeletal muscle and subsequently improve whole-body oxygen uptake capacity [180, 181]. However, the latter response may be attenuated in more advanced and older Type 2 diabetes patients [146, 182-185]. On the other hand, resistance-type exercise is able to induce muscle protein synthesis $[186,187]$ and, as such, represents an effective interventional strategy to increase lean body mass in both early [188] and advanced stage Type 2 diabetes patients [146, 189].

\section{Exercise modality}

In terms of physiological adaptations, apparent differences exist in the long-term adaptive response to endurance- or resistance-type exercise training. Prolonged endurancetype exercise training has been shown to improve insulin sensitivity in both young [190], elderly [191] and/or insulin-resistant subjects [178, 192-194]. The latter is attributed to the upregulation of skeletal muscle GLUT-4 expression, improved nitric oxide-mediated skeletal muscle blood flow and concomitant induction of weight loss [195], reduced hormonal stimulation of hepatic glucose output [196] and the normalization of blood lipids [197]. Longterm resistance-type exercise interventions have also been reported to improve glucose tolerance [157] and/or wholebody insulin sensitivity [172, 188, 198]. Besides the consecutive effects of each successive bout of exercise in acutely reducing glycogen stores [173, 199], resistancetype exercise training has been associated with a substantial gain in skeletal muscle mass, thereby improving whole-body glucose disposal capacity [172]. Besides the attenuation of the loss of muscle mass with aging, resistance-type exercise training also improves muscle strength and functional capacity, thereby allowing a healthier, more active lifestyle. Some studies report even greater benefits of resistance as opposed to endurance-type exercise training on glycemic control and insulin sensitivity in long-standing Type 2 diabetes patients [182]. However, recent evidence indicates that both types of exercise interventions have similar therapeutic strength in uncomplicated Type 2 diabetes patients [157]. Its combined application is probably more effective, especially in patients with $\mathrm{HbA}_{1 \mathrm{c}}$ levels $\geq 7.5 \%$ [157]. As such, it has been firmly established that both endurance- and resistance-type exercise training can be applied to improve metabolic control and quality of life in Type 2 diabetes patients [154].

Energy expenditure determines therapeutic strength of exercise

When prescribing exercise as treatment for an individual diabetes patient, it is important to estimate total energy expenditure that can be achieved through the recommended type of exercise. Several studies have shown that the energy equivalent of an endurance exercise bout represents the major determinant of the exercise-induced changes in glucose homeostasis [200-202]. To obtain durable metabolic improvements through exercise, the absolute minimum dose of weekly energy expenditure should entail $4.2 \mathrm{MJ}(\approx 1,000 \mathrm{kcal})$ [202], but for optimal results weekly energy expenditure should probably be twice as high [202, 203]. Therefore, a lesser exercise intensity should be compensated for by an increase in exercise duration.

Exercise in advanced stage Type 2 diabetes patients

Another expanding Type 2 diabetes subpopulation is formed by the long-standing, insulin treated, Type 2 diabetes patients [204]. These patients generally suffer from severe exercise intolerance due to the combination of low oxidative capacity [205], micro- and macrovascular disease [206, 207], neuropathy-related muscle weakness [207-210] and/or sarcopenia [211]. As generic exercise intervention programs are too demanding for most of these patients, it is of utmost importance to implement intermediate exercise intervention programs. Such intermediate programs are needed to bring the patient to a level at which they are able to participate in more generic diabetes intervention programs. Such intermediate programs should implement short, relatively high-intensity, exercise bouts applied in an intermittent fashion with the intention to increase muscle strength and functional performance. These so-called short 'ins-and-outs' exercises do not produce feelings of dyspnoea or discomfort and have been proven safe and effective in cardiac patients $[212,213]$. The efficacy and safety of such intermediate programs in long-standing Type 2 diabetes patients with high cardiovascular risk profile was recently confirmed in a small scale study by our research group [146]. Nevertheless, more larger scale trials are warranted since exercise intervention studies generally exclude this specific Type 2 diabetes subpopulation.

Interaction between exercise and blood glucose lowering medication

Type 2 diabetes is characterized by resistance to the actions of insulin in the presence of defects in insulin 
secretion. Absolute insulin levels vary with the severity of the disease; early stages tend to be characterized by a compensatory hyperinsulinemic state, but progressive beta-cell failure eventually occurs in most patients, leading to low basal fasting insulin levels [214]. Circulating insulin plays a critical role in regulating hepatic glucose output during exercise and has been shown to modulate peripheral glucose uptake during exercise and recovery [215-217]. Depending on the remaining insulin secretory capacity, the use of insulin secretagogues [183, 218, 219], the type of exogenous insulin used [220], as well as the level of peripheral insulin resistance, the glucose lowering effect of single bout of resistance or endurance bout of exercise may vary considerably. Moreover, as discussed in aforementioned paragraphs, the type, intensity and duration of exercise may result in different glycemic responses [182]. In accordance, failure to adequately adjust medication and/or carbohydrate supplementation can result in inappropriate swings in blood glucose levels, either too low or too high. In accordance with Type 1 diabetes patients [221, 222], antecedent hypoglycemia may also result in hypoglycemia unawareness in Type 2 diabetes [223] However, circumstances that result in inappropriate elevations in blood glucose levels (such as excessive carbohydrate supplementation or too large reductions in insulin dosage) also have long-term adverse implications [224-226]. Knowledge of the factors that affect glucose metabolism is critical for designing strategies to minimize inappropriate swings in blood glucose control related to exercise. As such, more research is required to better understand the complex interaction between the different exercise modalities and blood glucose lowering drugs. Nevertheless, in long-standing insulin-treated Type 2 diabetes patients, we have shown that frequent self-monitoring of blood glucose levels before and after each exercise bout is safe and feasible and results in improved glycemic control [146, 227].

Prevention of overload injuries in exercise training

Many patients with Type 2 diabetes experience not only cardio-respiratory [205], but also musculoskeletal deconditioning [207-210]. Obesity- and diabetes-related subclinical osteoarthritis [228, 229] on top of neuropathyrelated peripheral muscle weakness [210] have shown potential reasons for overload injuries and subsequent drop out $[157,230]$. In future, endurance type of exercise interventions, certain overuse injuries, might be prevented through adaptations in biomechanical loading on feet and lower extremities [231-234] as well as through the application of resistance-type exercise aimed at strengthening myotendinous structures. The latter concept is supported by resistance-type exercise studies that report long-term program adherence between $68 \%$ [235] and 72\% [236], without concomitant musculoskeletal overuse injuries. Nevertheless, more long-term tailored exercise intervention studies are needed to assess the usefulness of a differentiated approach.

Long-term program adherence in therapeutic exercise intervention programs

Long-term program adherence may vary between as much as 10 and $80 \%$ [142, 230, 235, 237, 238]. Therefore, motivational factors and time constraints should be considered to prevent long-term drop out rate. In accordance, future exercise interventions might benefit from psychological strategies such as motivational interviewing [239] or booster sessions [240-242]. Furthermore, restricting the travel time toward a training facility [243] and providing the patient with feedback on physical activity levels [244] may improve long-term adherence as well. Although aforementioned approaches are likely to reduce program drop out throughout the course of a supervised exercise program, scientific studies are warranted that combine aforementioned approaches.

\section{Safety considerations before initiating exercise therapy}

Before exposing patients with Type 2 diabetes to more vigorous exercise programs, the ADA and U.S. Preventive Services Task Force recommend exercise testing for silent myocardial ischemia (SMI) if 10-year cardiovascular risk exceeds $10 \%$ [169, 245]. Cardiac dysfunction [246] and SMI are estimated to be present between 6 and 22\% [247] of the Type 2 diabetes patients, with cardiac autonomic dysfunction, disease duration and male gender being the best predictors for SMI [247]. Moreover, poor physical fitness [248], scintigraphy abnormalities [249], diabetic retinopathy [249] and an advancing age $>60$ years [250] in combination with the traditional cardiac risk factors also represent good predictors for the likelihood of a cardiac event. The UKPDS Risk Engine v2.0 (available free of charge at www.dtu.ox.ac.uk) may be of help to calculate an individual patient's risk for coronary heart disease [251]. Although arbitrary, the UKPDS Risk Engine indicates that ECG stress testing in Type 2 diabetes is useful in most patients with $>2$ cardiovascular risk factors, in middleaged patients with a diabetes duration $>5$ years, as well in elderly patients $>70$ years. Although a stress ECG is not the most sensitive diagnostic tool to detect SMI [252] and predict coronary events [253], other research indicates that it is still the most cost-effective tool when trying to minimize the risk of a coronary event [254]. In case SMI is expected, more sensitive diagnostic tests such as myocardial perfusion scintigraphy [255], electron beam 
computerized tomography [256] and/or coronary angiography [257] should be considered before more vigorous exercise is prescribed. Even in the absence of SMI, a stress test will detect chronotropic incompetence [258] as well as exercise-related hypertension and provide more objective information on the individual fitness level [205]. Ideally, this information should be used to further tailor an exercise program for the individual patient with Type 2 diabetes [259].

Are structured exercise interventions cost-effective?

Previous lifestyle intervention studies indicate that longterm health benefits mainly depend on long-term program adherence as well as the level of motivation, coaching and supervision [235, 236, 260-263]. Depending on the level and duration of exercise supervision and dietary guidance, direct health care costs vary between $\sim 400$ and $\sim 2,000$ euro per individual participant [230, 264]. Although the cost-effectiveness of such (theoretical) interventions is more favorable in groups with high-risk populations compared with mixed populations [264], lifestyle intervention is considered highly cost-effective for the prevention of Type 2 diabetes [264-270]. As far as we know, no study has been published on the cost-effectiveness of similar lifestyle interventions in patients that have already developed Type 2 diabetes. However, direct costs of either a brisk walking or medical fitness program in Type 2 diabetes seem to be within the aforementioned range [230]. Although we could not determine the cost-effectiveness in the latter study, several larger scale multidisciplinary lifestyle interventions (e.g., the 'BeweegKuur' in the Netherlands [265] and the LookAHEAD study in the USA) [271] are underway. These studies should provide more insight into the cost-effectiveness of well-structured exercise interventions as a part of a multidisciplinary Type 2 diabetes care program consisting of medication, diet and exercise.

\section{Future research}

Based on a thorough review of the literature, we recently have proposed a more differentiated approach for exercise therapy in Type 2 diabetes [259]. However, before more differentiated exercise prescription guidelines can be used as clinical treatment guidelines, its medium to long-term efficacy should first be evaluated in more large-scale randomized controlled clinical trials. By definition, most randomized clinical trials completely disregard a patient's free choice or preference for a specific type of exercise. In fact, potentially interested patients may feel excluded, while others may find it difficult to adhere to a non-preferred type of exercise intervention. Therefore, to simulate a more realistic type of health care environment, randomized clinical trials should be performed in which subjects can choose from different exercise programs. Moreover, for each type of exercise intervention, control groups should perceive a similar amount of supervision and guidance. Such an approach is likely to result in higher adherence rates and will provide us with more definitive answers on how to implement exercise therapy more effectively in the chain of diabetes health care.

On top of these clinical and methodological issues, recent studies suggest that genetic factors [272, 273] should be considered to determine which subgroup Type 2 diabetes patients is likely to benefit the most from tailored exercise interventions. However, to unravel the proposed genetic influences, well-defined exercise intervention studies with a high compliance rate will be essential. Although such mechanistic studies often do not represent a realistic clinical approach, these studies should provide more insight into the pathomechanics of exercise intervention in Type 2 diabetes patients with a different genetic and/or co-morbidity profile. The combined approach of mechanistic and clinical implementation studies is expected to lead toward more specific and evidence-based exercise prescription guidelines that can optimize longterm therapeutic outcome at an affordable socio-economic cost price. Given the size and expanding nature of the Type 2 diabetes pandemic, the field of clinical diabetes research has the scientific, socio-economic and medical ethical obligation to contribute to such studies and move the field of diabetes care into action.

Open Access This article is distributed under the terms of the Creative Commons Attribution Noncommercial License which permits any noncommercial use, distribution, and reproduction in any medium, provided the original author(s) and source are credited.

\section{References}

1. Aretaeus (1972) Of Aretaeus, the Cappadocian. Causes and symptoms of chronic disease, Book I, Chapter II 'ON DIABETES'. In: Francis Adams LLD (ed) The extant works of Aretaeus, The Cappadocian. Digital Hippocrates Collection. A collection of ancient medical texts. Boston Milford House Inc., Milford, p 91 (Republication of the 1856 edition)

2. Lancereaux E (1880) Le diabete maigre: ses symptomes, son evolution, son prognostie et son traitement. Un. Med Paris 20:205-211

3. Pincus G, Joslin EP, White P (1934) Age-incidence relations in diabetes mellitus. Am J Med Sci 188:116-121

4. Zimmet P (2000) Globalization, coca-colonization and the chronic disease epidemic: can the Doomsday scenario be averted? J Intern Med 247:301-310

5. Engelgau MM, Geiss LS, Saaddine JB et al (2004) The evolving diabetes burden in the United States. Ann Intern Med 140:945950 
6. Seidell JC (2000) Obesity, insulin resistance and diabetes-a worldwide epidemic. Br J Nutr 83(Suppl 1):S5-S8

7. Mokdad AH, Bowman BA, Ford ES, Vinicor F, Marks JS, Koplan JP (2001) The continuing epidemics of obesity and diabetes in the United States. JAMA 286:1195-1200

8. Sladek R, Rocheleau G, Rung J et al (2007) A genome-wide association study identifies novel risk loci for type 2 diabetes. Nature 445:881-885

9. Saxena R, Voight BF, Lyssenko V et al (2007) Genome-wide association analysis identifies loci for type 2 diabetes and triglyceride levels. Science 316:1331-1336

10. Prokopenko I, Langenberg C, Florez JC et al (2009) Variants in MTNR1B influence fasting glucose levels. Nat Genet 41:77-81

11. Cauchi S, Meyre D, Durand E et al (2008) Post genome-wide association studies of novel genes associated with type 2 diabetes show gene-gene interaction and high predictive value. PLoS ONE 3:e2031

12. Sullivan PW, Morrato EH, Ghushchyan V, Wyatt HR, Hill JO (2005) Obesity, inactivity, and the prevalence of diabetes and diabetes-related cardiovascular comorbidities in the US, 20002002. Diabetes Care 28:1599-1603

13. van Hoek M, Dehghan A, Witteman JC et al (2008) Predicting type 2 diabetes based on polymorphisms from genome-wide association studies: a population-based study. Diabetes 57:3122-3128

14. Lyssenko V, Groop L (2009) Genome-wide association study for type 2 diabetes: clinical applications. Curr Opin Lipidol 20:87-91

15. IDF (2008) Diabetes: a global threat. Diabetes Atlas, 3rd edn. IDF, Brussels, pp 1-15. http://www.eatlas.idf.org/index1397. html

16. World Health Organization Expert Committee (1999) Definition, diagnosis and classification of diabetes mellitus and its complications. Part 1: diagnosis and classification of diabetes mellitus. World Health Organization, Geneva

17. WHO/IDF (2006) Definition and diagnosis of diabetes mellitus and intermediate hyperglycemia: report of a WHO/IDF consultation. World Health Organisation, Geneva

18. Costa B, Vizcaino J, Pinol JL, Cabre JJ, Fuentes CM (2007) Relevance of casual undetected hyperglycemia among high-risk individuals for developing diabetes. Diabetes Res Clin Pract 78:289-292

19. Manders RJ, Praet SF, Vikstrom MH, Saris WH, van Loon LJ (2009) Protein hydrolysate co-ingestion does not modulate $24 \mathrm{~h}$ glycemic control in long-standing type 2 diabetes patients. Eur $\mathbf{J}$ Clin Nutr 63:121-126

20. Praet SF, Manders RJ, Meex RC et al (2006) Glycaemic instability is an underestimated problem in Type II diabetes. Clin Sci (Lond) 111:119-126

21. Ceriello A (2005) Postprandial hyperglycemia and diabetes complications: is it time to treat? Diabetes 54:1-7

22. Baron AD (2001) Impaired glucose tolerance as a disease. Am J Cardiol $88: 16 \mathrm{H}-19 \mathrm{H}$

23. Stumvoll M, Goldstein BJ, van Haeften TW (2005) Type 2 diabetes: principles of pathogenesis and therapy. Lancet 365:1333-1346

24. Perry JR, Mc Carthy MI, Hattersley AT, Zeggini E, Weedon MN, Frayling TM (2009) Interrogating Type 2 diabetes genomewide association data using a biological pathway-based approach. Diabetes 58:1463-1467

25. Perseghin G, Ghosh S, Gerow K, Shulman GI (1997) Metabolic defects in lean nondiabetic offspring of NIDDM parents: a cross-sectional study. Diabetes 46:1001-1009

26. Taylor R (2008) Pathogenesis of type 2 diabetes: tracing the reverse route from cure to cause. Diabetologia 51:17811789
27. Robertson RP, Harmon J, Tran PO, Tanaka Y, Takahashi H (2003) Glucose toxicity in beta-cells: type 2 diabetes, good radicals gone bad, and the glutathione connection. Diabetes 52:581-587

28. Dubois M, Kerr-Conte J, Gmyr V et al (2004) Non-esterified fatty acids are deleterious for human pancreatic islet function at physiological glucose concentration. Diabetologia 47:463-469

29. Hull RL, Westermark GT, Westermark P, Kahn SE (2004) Islet amyloid: a critical entity in the pathogenesis of type 2 diabetes. $J$ Clin Endocrinol Metab 89:3629-3643

30. Kahn SE, Haffner SM, Heise MA et al (2006) Glycemic durability of rosiglitazone, metformin, or glyburide monotherapy. N Engl J Med 355:2427-2443

31. Holst JJ (2006) Glucagon-like peptide-1: from extract to agent. The Claude Bernard lecture, 2005. Diabetologia 49:253-260

32. Drucker DJ, Nauck MA (2006) The incretin system: glucagonlike peptide-1 receptor agonists and dipeptidyl peptidase-4 inhibitors in type 2 diabetes. Lancet 368:1696-1705

33. D'Alessio DA, Denney AM, Hermiller LM et al (2009) Treatment with the dipeptidyl peptidase-4 inhibitor vildagliptin improves fasting islet-cell function in subjects with type 2 diabetes. J Clin Endocrinol Metab 94:81-88

34. Rosenstock J, Foley JE, Rendell M et al (2008) Effects of the dipeptidyl peptidase-IV inhibitor vildagliptin on incretin hormones, islet function, and postprandial glycemia in subjects with impaired glucose tolerance. Diabetes Care 31:30-35

35. Ahren B, Schweizer A, Dejager S et al (2009) Vildagliptin enhances islet responsiveness to both hyper- and hypoglycemia in patients with Type 2 diabetes. J Clin Endocrinol Metab 94:1236-1243

36. Ferrannini E, Fonseca V, Zinman B et al (2009) Fifty-two-week efficacy and safety of vildagliptin vs. glimepiride in patients with type 2 diabetes mellitus inadequately controlled on metformin monotherapy. Diabetes Obes Metab 11:157-166

37. Goke B, Hershon K, Kerr D et al (2008) Efficacy and safety of vildagliptin monotherapy during 2-year treatment of drug-naive patients with type 2 diabetes: comparison with metformin. Horm Metab Res 40:892-895

38. Moretto TJ, Milton DR, Ridge TD et al (2008) Efficacy and tolerability of exenatide monotherapy over 24 weeks in antidiabetic drug-naive patients with type 2 diabetes: a randomized, double-blind, placebo-controlled, parallel-group study. Clin Ther 30:1448-1460

39. Hermansen K, Kipnes M, Luo E, Fanurik D, Khatami H, Stein P (2007) Efficacy and safety of the dipeptidyl peptidase-4 inhibitor, sitagliptin, in patients with type 2 diabetes mellitus inadequately controlled on glimepiride alone or on glimepiride and metformin. Diabetes Obes Metab 9:733-745

40. Jenkins DJ, Kendall CW, Augustin LS, Vuksan V (2002) Highcomplex carbohydrate or lente carbohydrate foods? Am J Med 113(Suppl 9B):30S-37S

41. Manders RJ, Praet SF, Meex RC et al (2006) Protein hydrolysate/leucine co-ingestion reduces the prevalence of hyperglycemia in type 2 diabetic patients. Diabetes Care 29:2721-2722

42. Manders RJ, Koopman R, Sluijsmans WE et al (2006) Coingestion of a protein hydrolysate with or without additional leucine effectively reduces postprandial blood glucose excursions in Type 2 diabetic men. J Nutr 136:1294-1299

43. van Loon LJ, Kruijshoop M, Menheere PP, Wagenmakers AJ, Saris WH, Keizer HA (2003) Amino acid ingestion strongly enhances insulin secretion in patients with long-term type 2 diabetes. Diabetes Care 26:625-630

44. Frid AH, Nilsson M, Holst JJ, Bjorck IM (2005) Effect of whey on blood glucose and insulin responses to composite breakfast and lunch meals in type 2 diabetic subjects. Am J Clin Nutr 82:69-75 
45. Nathan DM, Buse JB, Davidson MB et al (2006) Management of hyperglycemia in type 2 diabetes: a consensus algorithm for the initiation and adjustment of therapy: a consensus statement from the American Diabetes Association and the European Association for the Study of Diabetes. Diabetes Care 29:19631972

46. Kahn SE, Hull RL, Utzschneider KM (2006) Mechanisms linking obesity to insulin resistance and type 2 diabetes. Nature 444:840-846

47. Boden G, Chen X (1995) Effects of fat on glucose uptake and utilization in patients with non-insulin-dependent diabetes. J Clin Invest 96:1261-1268

48. Boden G (1997) Role of fatty acids in the pathogenesis of insulin resistance and NIDDM. Diabetes 46:3-10

49. Kabir M, Catalano KJ, Ananthnarayan S et al (2005) Molecular evidence supporting the portal theory: a causative link between visceral adiposity and hepatic insulin resistance. Am J Physiol Endocrinol Metab 288:E454-E461

50. Petersen KF, Dufour S, Befroy D, Lehrke M, Hendler RE, Shulman GI (2005) Reversal of nonalcoholic hepatic steatosis, hepatic insulin resistance, and hyperglycemia by moderate weight reduction in patients with type 2 diabetes. Diabetes 54:603-608

51. Mooney RA, Senn J, Cameron S et al (2001) Suppressors of cytokine signaling- 1 and -6 associate with and inhibit the insulin receptor. A potential mechanism for cytokine-mediated insulin resistance. J Biol Chem 276:25889-25893

52. Perreault M, Marette A (2001) Targeted disruption of inducible nitric oxide synthase protects against obesity-linked insulin resistance in muscle. Nat Med 7:1138-1143

53. Xu H, Barnes GT, Yang Q et al (2003) Chronic inflammation in fat plays a crucial role in the development of obesity-related insulin resistance. J Clin Invest 112:1821-1830

54. Graham TE, Yang Q, Bluher M et al (2006) Retinol-binding protein 4 and insulin resistance in lean, obese, and diabetic subjects. N Engl J Med 354:2552-2563

55. Yang Q, Graham TE, Mody N et al (2005) Serum retinol binding protein 4 contributes to insulin resistance in obesity and type 2 diabetes. Nature 436:356-362

56. Balagopal P, Graham TE, Kahn BB, Altomare A, Funanage V, George D (2007) Reduction of elevated serum retinol binding protein in obese children by lifestyle intervention: association with subclinical inflammation. J Clin Endocrinol Metab 92:1971-1974

57. Haider DG, Schindler K, Mittermayer F et al (2007) Effect of rosiglitazone on visfatin and retinol-binding protein-4 plasma concentrations in HIV-positive patients. Clin Pharmacol Ther $81: 580-585$

58. Haider DG, Schindler K, Prager G et al (2007) Serum retinolbinding protein 4 is reduced after weight loss in morbidly obese subjects. J Clin Endocrinol Metab 92:1168-1171

59. Furler SM, Gan SK, Poynten AM, Chisholm DJ, Campbell LV, Kriketos AD (2006) Relationship of adiponectin with insulin sensitivity in humans, independent of lipid availability. Obesity (Silver Spring) 14:228-234

60. Kadowaki T, Yamauchi T, Kubota N, Hara K, Ueki K, Tobe K (2006) Adiponectin and adiponectin receptors in insulin resistance, diabetes, and the metabolic syndrome. J Clin Invest 116:1784-1792

61. Pedersen BK (2006) The anti-inflammatory effect of exercise: its role in diabetes and cardiovascular disease control. Essays Biochem 42:105-117

62. van Loon LJ, Goodpaster BH (2006) Increased intramuscular lipid storage in the insulin-resistant and endurance-trained state. Pflugers Arch 451:606-616
63. Larson-Meyer DE, Heilbronn LK, Redman LM et al (2006) Effect of calorie restriction with or without exercise on insulin sensitivity, beta-cell function, fat cell size, and ectopic lipid in overweight subjects. Diabetes Care 29:1337-1344

64. Bruce CR, Kriketos AD, Cooney GJ, Hawley JA (2004) Disassociation of muscle triglyceride content and insulin sensitivity after exercise training in patients with Type 2 diabetes. Diabetologia 47:23-30

65. van Loon LJ, Manders RJ, Koopman R et al (2005) Inhibition of adipose tissue lipolysis increases intramuscular lipid use in type 2 diabetic patients. Diabetologia 48:2097-2107

66. van Loon LJ, Thomason-Hughes M, Constantin-Teodosiu D et al (2005) Inhibition of adipose tissue lipolysis increases intramuscular lipid and glycogen use in vivo in humans. Am J Physiol Endocrinol Metab 289:E482-E493

67. van Loon LJ, Koopman R, Manders R, van der Weegen W, van Kranenburg GP, Keizer HA (2004) Intramyocellular lipid content in type 2 diabetes patients compared with overweight sedentary men and highly trained endurance athletes. Am J Physiol Endocrinol Metab 287:E558-E565

68. Boon H, Blaak EE, Saris WH, Keizer HA, Wagenmakers AJ, van Loon LJ (2007) Substrate source utilisation in long-term diagnosed type 2 diabetes patients at rest, and during exercise and subsequent recovery. Diabetologia 50:103-112

69. Russell AP, Gastaldi G, Bobbioni-Harsch E et al (2003) Lipid peroxidation in skeletal muscle of obese as compared to endurance-trained humans: a case of good vs. bad lipids? FEBS Lett 551:104-106

70. Petersen KF, Shulman GI (2006) Etiology of insulin resistance. Am J Med 119:S10-S16

71. Shulman GI (2000) Cellular mechanisms of insulin resistance. J Clin Invest 106:171-176

72. Ryysy L, Hakkinen AM, Goto T et al (2000) Hepatic fat content and insulin action on free fatty acids and glucose metabolism rather than insulin absorption are associated with insulin requirements during insulin therapy in type 2 diabetic patients. Diabetes 49:749-758

73. Cai D, Yuan M, Frantz DF et al (2005) Local and systemic insulin resistance resulting from hepatic activation of IKK-beta and NF-kappaB. Nat Med 11:183-190

74. Samuel VT, Liu ZX, Qu X et al (2004) Mechanism of hepatic insulin resistance in non-alcoholic fatty liver disease. J Biol Chem 279:32345-32353

75. Samuel VT, Liu ZX, Wang A et al (2007) Inhibition of protein kinase Cepsilon prevents hepatic insulin resistance in nonalcoholic fatty liver disease. J Clin Invest 117:739-745

76. Goldin A, Beckman JA, Schmidt AM, Creager MA (2006) Advanced glycation end products: sparking the development of diabetic vascular injury. Circulation 114:597-605

77. Schalkwijk CG, Lieuw-a-Fa M, van Hinsbergh VW, Stehouwer CD (2002) Pathophysiological role of Amadori-glycated proteins in diabetic microangiopathy. Semin Vasc Med 2:191-197

78. Brownlee M (2001) Biochemistry and molecular cell biology of diabetic complications. Nature 414:813-820

79. Hogan M, Cerami A, Bucala R (1992) Advanced glycosylation endproducts block the antiproliferative effect of nitric oxide. Role in the vascular and renal complications of diabetes mellitus. J Clin Invest 90:1110-1115

80. Nishikawa T, Edelstein D, Brownlee M (2000) The missing link: a single unifying mechanism for diabetic complications. Kidney Int Suppl 77:S26-S30

81. Vincent AM, Perrone L, Sullivan KA et al (2007) Receptor for advanced glycation end products activation injures primary sensory neurons via oxidative stress. Endocrinology 148:548558 
82. Evans JL, Goldfine ID, Maddux BA, Grodsky GM (2002) Oxidative stress and stress-activated signaling pathways: a unifying hypothesis of type 2 diabetes. Endocr Rev 23:599622

83. Wada R, Yagihashi S (2005) Role of advanced glycation end products and their receptors in development of diabetic neuropathy. Ann N Y Acad Sci 1043:598-604

84. Rosen P, Nawroth PP, King G, Moller W, Tritschler HJ, Packer L (2001) The role of oxidative stress in the onset and progression of diabetes and its complications: a summary of a Congress Series sponsored by UNESCO-MCBN, the American Diabetes Association and the German Diabetes Society. Diabetes Metab Res Rev 17:189-212

85. Da Ros R, Assaloni R, Ceriello A (2005) Molecular targets of diabetic vascular complications and potential new drugs. Curr Drug Targets 6:503-509

86. Stitt A, Gardiner TA, Alderson NL et al (2002) The AGE inhibitor pyridoxamine inhibits development of retinopathy in experimental diabetes. Diabetes 51:2826-2832

87. Ji LL (2002) Exercise-induced modulation of antioxidant defense. Ann N Y Acad Sci 959:82-92

88. Stoppa GR, Cesquini M, Roman EA, Ogo SH, Torsoni MA (2006) Aminoguanidine prevented impairment of blood antioxidant system in insulin-dependent diabetic rats. Life Sci 78:1352-1361

89. Saengsirisuwan V, Perez FR, Sloniger JA, Maier T, Henriksen EJ (2004) Interactions of exercise training and alpha-lipoic acid on insulin signaling in skeletal muscle of obese Zucker rats. Am J Physiol Endocrinol Metab 287:E529-E536

90. Balducci S, Iacobellis G, Parisi L et al (2006) Exercise training can modify the natural history of diabetic peripheral neuropathy. J Diabetes Complications 20:216-223

91. Ziegler D, Ametov A, Barinov A et al (2006) Oral treatment with alpha-lipoic acid improves symptomatic diabetic polyneuropathy: the SYDNEY 2 trial. Diabetes Care 29:2365-2370

92. Henriksen EJ (2006) Exercise training and the antioxidant alpha-lipoic acid in the treatment of insulin resistance and type 2 diabetes. Free Radic Biol Med 40:3-12

93. Regensteiner JG, Sippel J, McFarling ET, Wolfel EE, Hiatt WR (1995) Effects of non-insulin-dependent diabetes on oxygen consumption during treadmill exercise. Med Sci Sports Exerc 27:875-881

94. Regensteiner JG, Bauer TA, Reusch JE et al (1998) Abnormal oxygen uptake kinetic responses in women with type II diabetes mellitus. J Appl Physiol 85:310-317

95. Estacio RO, Wolfel EE, Regensteiner JG et al (1996) Effect of risk factors on exercise capacity in NIDDM. Diabetes 45:79-85

96. Lowell BB, Shulman GI (2005) Mitochondrial dysfunction and type 2 diabetes. Science 307:384-387

97. De Feyter HM, van den Broek NM, Praet SF, Nicolay K, van Loon LJ, Prompers JJ (2008) Early or advanced stage type 2 diabetes is not accompanied by in vivo skeletal muscle mitochondrial dysfunction. Eur J Endocrinol 158:643-653

98. Trenell MI, Hollingsworth KG, Lim EL, Taylor R (2008) Increased daily walking improves lipid oxidation without changes in mitochondrial function in Type 2 diabetes. Diabetes Care 31:1644-1649

99. Petersen KF, Dufour S, Befroy D, Garcia R, Shulman GI (2004) Impaired mitochondrial activity in the insulin-resistant offspring of patients with type 2 diabetes. N Engl J Med 350:664-671

100. Petersen KF, Befroy D, Dufour S et al (2003) Mitochondrial dysfunction in the elderly: possible role in insulin resistance. Science 300:1140-1142

101. Kelley DE, He J, Menshikova EV, Ritov VB (2002) Dysfunction of mitochondria in human skeletal muscle in type 2 diabetes. Diabetes 51:2944-2950
102. Short KR, Nair KS, Stump CS (2004) Impaired mitochondrial activity and insulin-resistant offspring of patients with type 2 diabetes. N Engl J Med 350:2419-2421; author reply 2419-2421

103. Simoneau JA, Kelley DE (1997) Altered glycolytic and oxidative capacities of skeletal muscle contribute to insulin resistance in NIDDM. J Appl Physiol 83:166-171

104. Rabol R, Boushel R, Dela F (2006) Mitochondrial oxidative function and type 2 diabetes. Appl Physiol Nutr Metab 31:675683

105. Szendroedi J, Schmid AI, Chmelik M et al (2007) Muscle mitochondrial ATP synthesis and glucose transport/phosphorylation in type 2 diabetes. PLoS Med 4:e154

106. Hawley JA, Lessard SJ (2007) Mitochondrial function: use it or lose it. Diabetologia 50:699-702

107. Schrauwen-Hinderling VB, Kooi ME, Hesselink MK et al (2007) Impaired in vivo mitochondrial function but similar intramyocellular lipid content in patients with type 2 diabetes mellitus and BMI-matched control subjects. Diabetologia 50:113-120

108. Sirikul B, Gower BA, Hunter GR, Larson-Meyer DE, Newcomer BR (2006) Relationship between insulin sensitivity and in vivo mitochondrial function in skeletal muscle. Am J Physiol Endocrinol Metab 291:E724-E728

109. Mogensen M, Sahlin K, Fernstrom M et al (2007) Mitochondrial respiration is decreased in skeletal muscle of patients with type 2 diabetes. Diabetes 56:1592-1599

110. Boushel R, Gnaiger E, Schjerling P, Skovbro M, Kraunsoe R, Dela F (2007) Patients with type 2 diabetes have normal mitochondrial function in skeletal muscle. Diabetologia 50:790-796

111. Brons C, Jensen CB, Storgaard H et al (2008) Mitochondrial function in skeletal muscle is normal and unrelated to insulin action in young men born with low birth weight. J Clin Endocrinol Metab 93:3885-3892

112. Schwartz MW, Porte D Jr (2005) Diabetes, obesity, and the brain. Science 307:375-379

113. Porte D Jr, Baskin DG, Schwartz MW (2005) Insulin signaling in the central nervous system: a critical role in metabolic homeostasis and disease from $C$. elegans to humans. Diabetes 54:1264-1276

114. Landsberg L (2001) Insulin-mediated sympathetic stimulation: role in the pathogenesis of obesity-related hypertension (or, how insulin affects blood pressure, and why). J Hypertens 19:523528

115. Muntzel MS, Anderson EA, Johnson AK, Mark AL (1995) Mechanisms of insulin action on sympathetic nerve activity. Clin Exp Hypertens 17:39-50

116. Dunbar JC, Lu H (1999) Leptin-induced increase in sympathetic nervous and cardiovascular tone is mediated by proopiomelanocortin (POMC) products. Brain Res Bull 50:215-221

117. Tentolouris N, Liatis S, Katsilambros N (2006) Sympathetic system activity in obesity and metabolic syndrome. Ann N Y Acad Sci 1083:129-152

118. Frontoni S, Bracaglia D, Baroni A et al (2003) Early autonomic dysfunction in glucose-tolerant but insulin-resistant offspring of type 2 diabetic patients. Hypertension 41:1223-1227

119. Vinik AI, Maser RE, Mitchell BD, Freeman R (2003) Diabetic autonomic neuropathy. Diabetes Care 26:1553-1579

120. Ziegler D, Zentai C, Perz S et al (2006) Selective contribution of diabetes and other cardiovascular risk factors to cardiac autonomic dysfunction in the general population. Exp Clin Endocrinol Diabetes 114:153-159

121. Nesto RW (2004) Correlation between cardiovascular disease and diabetes mellitus: current concepts. Am J Med 116(Suppl $5 \mathrm{~A}): 11 \mathrm{~S}-22 \mathrm{~S}$

122. Spijkerman AM, Henry RM, Dekker JM et al (2004) Prevalence of macrovascular disease amongst type 2 diabetic patients 
detected by targeted screening and patients newly diagnosed in general practice: the Hoorn Screening Study. J Intern Med 256:429-436

123. Gerritsen J, Dekker JM, TenVoorde BJ et al (2001) Impaired autonomic function is associated with increased mortality, especially in subjects with diabetes, hypertension, or a history of cardiovascular disease: the Hoorn Study. Diabetes Care 24:1793-1798

124. Colhoun HM, Betteridge DJ, Durrington PN et al (2004) Primary prevention of cardiovascular disease with atorvastatin in type 2 diabetes in the Collaborative Atorvastatin Diabetes Study (CARDS): multicentre randomised placebo-controlled trial. Lancet 364:685-696

125. Scott R, O'Brien R, Fulcher G et al (2009) Effects of fenofibrate treatment on cardiovascular disease risk in 9, 795 individuals with type 2 diabetes and various components of the metabolic syndrome: the Fenofibrate Intervention and Event Lowering in Diabetes (FIELD) study. Diabetes Care 32:493-498

126. Patel A, MacMahon S, Chalmers J et al (2007) Effects of a fixed combination of perindopril and indapamide on macrovascular and microvascular outcomes in patients with type 2 diabetes mellitus (the ADVANCE trial): a randomised controlled trial. Lancet 370:829-840

127. Turner R et al (1998) Tight blood pressure control and risk of macrovascular and microvascular complications in type 2 diabetes: UKPDS 38. UK Prospective Diabetes Study Group. Br Med J 317:703-713

128. Skyler JS, Bergenstal R, Bonow RO et al (2009) Intensive glycemic control and the prevention of cardiovascular events: implications of the ACCORD, ADVANCE, and VA diabetes trials: a position statement of the American Diabetes Association and a scientific statement of the American College of Cardiology Foundation and the American Heart Association. Diabetes Care 32:187-192

129. Stratton IM, Cull CA, Adler AI, Matthews DR, Neil HA, Holman RR (2006) Additive effects of glycaemia and blood pressure exposure on risk of complications in type 2 diabetes: a prospective observational study (UKPDS 75). Diabetologia 49:1761-1769

130. UK Prospective Diabetes Study Group U (1998) Intensive blood-glucose control with sulphonylureas or insulin compared with conventional treatment and risk of complications in patients with type 2 diabetes (UKPDS 33). Lancet 352:837-853

131. Ohkubo Y, Kishikawa H, Araki E et al (1995) Intensive insulin therapy prevents the progression of diabetic microvascular complications in Japanese patients with non-insulin-dependent diabetes mellitus: a randomized prospective 6-year study. Diabetes Res Clin Pract 28:103-117

132. Patel A, MacMahon S, Chalmers J et al (2008) Intensive blood glucose control and vascular outcomes in patients with type 2 diabetes. N Engl J Med 358:2560-2572

133. Nissen SE, Wolski K (2007) Effect of rosiglitazone on the risk of myocardial infarction and death from cardiovascular causes. N Engl J Med 356:2457-2471

134. Gerstein HC, Miller ME, Byington RP et al (2008) Effects of intensive glucose lowering in type 2 diabetes. $\mathrm{N}$ Engl $\mathrm{J}$ Med 358:2545-2559

135. Duckworth W, Abraira C, Moritz T et al (2009) Glucose control and vascular complications in veterans with type 2 diabetes. $\mathrm{N}$ Engl J Med 360:129-139

136. Pi-Sunyer X, Blackburn G, Brancati FL et al (2007) Reduction in weight and cardiovascular disease risk factors in individuals with type 2 diabetes: one-year results of the look AHEAD trial. Diabetes Care 30:1374-1383

137. Dunstan DW, Mori TA, Puddey IB et al (1997) The independent and combined effects of aerobic exercise and dietary fish intake on serum lipids and glycemic control in NIDDM. A randomized controlled study. Diabetes Care 20:913-921

138. Lindstrom J, Ilanne-Parikka P, Peltonen M et al (2006) Sustained reduction in the incidence of type 2 diabetes by lifestyle intervention: follow-up of the Finnish Diabetes Prevention Study. Lancet 368:1673-1679

139. Vanninen E, Uusitupa M, Siitonen O, Laitinen J, Lansimies E (1992) Habitual physical activity, aerobic capacity and metabolic control in patients with newly-diagnosed type 2 (noninsulin-dependent) diabetes mellitus: effect of 1-year diet and exercise intervention. Diabetologia 35:340-346

140. Torjesen PA, Birkeland KI, Anderssen SA, Hjermann I, Holme I, Urdal P (1997) Lifestyle changes may reverse development of the insulin resistance syndrome. The Oslo Diet and Exercise Study: a randomized trial. Diabetes Care 20:26-31

141. Kishimoto H, Taniguchi A, Fukushima M et al (2002) Effect of short-term low-intensity exercise on insulin sensitivity, insulin secretion, and glucose and lipid metabolism in nonobese Japanese type 2 diabetic patients. Horm Metab Res 34:27-31

142. Balducci S, Leonetti F, Di Mario U, Fallucca F (2004) Is a longterm aerobic plus resistance training program feasible for and effective on metabolic profiles in type 2 diabetic patients? Diabetes Care 27:841-842

143. Pedersen BK, Febbraio MA (2008) Muscle as an endocrine organ: focus on muscle-derived interleukin-6. Physiol Rev 88:1379-1406

144. Madsen EL, Rissanen A, Bruun JM et al (2008) Weight loss larger than $10 \%$ is needed for general improvement of levels of circulating adiponectin and markers of inflammation in obese subjects: a 3-year weight loss study. Eur J Endocrinol 158:179187

145. Monzillo LU, Hamdy O, Horton ES et al (2003) Effect of lifestyle modification on adipokine levels in obese subjects with insulin resistance. Obes Res 11:1048-1054

146. De Feyter HM, Praet SF, van den Broek NM et al (2007) Exercise training improves glycemic control in long-standing, insulin-treated type 2 diabetes patients. Diabetes Care 30:25112513

147. Lambert CP, Wright NR, Finck BN, Villareal DT (2008) Exercise but not diet-induced weight loss decreases skeletal muscle inflammatory gene expression in frail obese elderly persons. J Appl Physiol 105:473-478

148. Castellano V, Patel DI, White LJ (2008) Cytokine responses to acute and chronic exercise in multiple sclerosis. J Appl Physiol 104:1697-1702

149. Stewart LK, Flynn MG, Campbell WW et al (2007) The influence of exercise training on inflammatory cytokines and Creactive protein. Med Sci Sports Exerc 39:1714-1719

150. Goldhammer E, Tanchilevitch A, Maor I, Beniamini Y, Rosenschein U, Sagiv M (2005) Exercise training modulates cytokines activity in coronary heart disease patients. Int J Cardiol 100:93-99

151. Mattusch F, Dufaux B, Heine O, Mertens I, Rost R (2000) Reduction of the plasma concentration of C-reactive protein following nine months of endurance training. Int J Sports Med 21:21-24

152. Starkie R, Ostrowski SR, Jauffred S, Febbraio M, Pedersen BK (2003) Exercise and IL-6 infusion inhibit endotoxin-induced TNF-alpha production in humans. FASEB J 17:884-886

153. Thomas DE, Elliott EJ, Naughton GA (2006) Exercise for type 2 diabetes mellitus. Cochrane Database Syst Rev 3:CD002968

154. Snowling NJ, Hopkins WG (2006) Effects of different modes of exercise training on glucose control and risk factors for complications in type 2 diabetic patients: a meta-analysis. Diabetes Care 29:2518-2527 
155. Halle M, Berg A, Garwers U et al (1999) Influence of 4 weeks' intervention by exercise and diet on low-density lipoprotein subfractions in obese men with type 2 diabetes. Metabolism 48:641-644

156. Krook A, Holm I, Pettersson S, Wallberg-Henriksson H (2003) Reduction of risk factors following lifestyle modification programme in subjects with type 2 (non-insulin dependent) diabetes mellitus. Clin Physiol Funct Imaging 23:21-30

157. Sigal RJ, Kenny GP, Boule NG et al (2007) Effects of aerobic training, resistance training, or both on glycemic control in type 2 diabetes: a randomized trial. Ann Intern Med 147:357-369

158. Miller WC, Koceja DM, Hamilton EJ (1997) A meta-analysis of the past 25 years of weight loss research using diet, exercise or diet plus exercise intervention. Int J Obes Relat Metab Disord 21:941-947

159. Westerterp KR (1999) Obesity and physical activity. Int J Obes Relat Metab Disord 23(Suppl 1):59-64

160. Hansen D, Dendale P, Berger J, van Loon LJ, Meeusen R (2007) The effects of exercise training on fat-mass loss in obese patients during energy intake restriction. Sports Med 37:31-46

161. Stich V, Berlan M (2004) Physiological regulation of NEFA availability: lipolysis pathway. Proc Nutr Soc 63:369-374

162. Paglialunga S, Cianflone K (2007) Regulation of postprandial lipemia: an update on current trends. Appl Physiol Nutr Metab 32:61-75

163. Stolinski M, Alam S, Jackson NC et al (2008) Effect of 6-month supervised exercise on low-density lipoprotein apolipoprotein B kinetics in patients with type 2 diabetes mellitus. Metabolism 57:1608-1614

164. Perseghin G, Lattuada G, De Cobelli F et al (2007) Habitual physical activity is associated with intrahepatic fat content in humans. Diabetes Care 30:683-688

165. Shojaee-Moradie F, Baynes KC, Pentecost C et al (2007) Exercise training reduces fatty acid availability and improves the insulin sensitivity of glucose metabolism. Diabetologia 50:404-413

166. Tamura Y, Tanaka Y, Sato F et al (2005) Effects of diet and exercise on muscle and liver intracellular lipid contents and insulin sensitivity in type 2 diabetic patients. J Clin Endocrinol Metab 90:3191-3196

167. Pastromas S, Terzi AB, Tousoulis D, Koulouris S (2008) Postprandial lipemia: an under-recognized atherogenic factor in patients with diabetes mellitus. Int J Cardiol 7:3-12

168. American Diabetes Association (2009) Standards of medical care in diabetes-2009. Diabetes Care 32(Suppl 1):S13-S61

169. Sigal RJ, Kenny GP, Wasserman DH, Castaneda-Sceppa C, White RD (2006) Physical activity/exercise and type 2 diabetes: a consensus statement from the American Diabetes Association. Diabetes Care 29:1433-1438

170. American Diabetes Association (2009) Standards of medical care in diabetes-2009. Diabetes Care 32(Suppl 1):S13-S64

171. Devlin JT, Hirshman M, Horton ED, Horton ES (1987) Enhanced peripheral and splanchnic insulin sensitivity in NIDDM men after single bout of exercise. Diabetes 36:434-439

172. Fenicchia LM, Kanaley JA, Azevedo JL Jr et al (2004) Influence of resistance exercise training on glucose control in women with type 2 diabetes. Metabolism 53:284-289

173. Koopman R, Manders RJ, Zorenc AH et al (2005) A single session of resistance exercise enhances insulin sensitivity for at least $24 \mathrm{~h}$ in healthy men. Eur J Appl Physiol 94:180-187

174. Garcia-Roves PM, Han DH, Song Z, Jones TE, Hucker KA, Holloszy JO (2003) Prevention of glycogen supercompensation prolongs the increase in muscle GLUT4 after exercise. Am J Physiol Endocrinol Metab 285:E729-E736

175. Sriwijitkamol A, Coletta DK, Wajcberg E et al (2007) Effect of acute exercise on AMPK signaling in skeletal muscle of subjects with type 2 diabetes: a time-course and dose-response study. Diabetes 56:836-848

176. Pencek RR, Fueger PT, Camacho RC, Wasserman DH (2005) Mobilization of glucose from the liver during exercise and replenishment afterward. Can J Appl Physiol 30:292-303

177. Price TB, Rothman DL, Shulman RG (1999) NMR of glycogen in exercise. Proc Nutr Soc 58:851-859

178. Dela F, Larsen JJ, Mikines KJ, Ploug T, Petersen LN, Galbo H (1995) Insulin-stimulated muscle glucose clearance in patients with NIDDM. Effects of one-legged physical training. Diabetes 44:1010-1020

179. Bisquolo VA, Cardoso CG Jr, Ortega KC et al (2005) Previous exercise attenuates muscle sympathetic activity and increases blood flow during acute euglycemic hyperinsulinemia. J Appl Physiol 98:866-871

180. Mandroukas K, Krotkiewski M, Holm G et al (1986) Muscle adaptations and glucose control after physical training in insulin-dependent diabetes mellitus. Clin Physiol 6:39-52

181. Henriksson J (1992) Effects of physical training on the metabolism of skeletal muscle. Diabetes Care 15:1701-1711

182. Cauza E, Hanusch-Enserer U, Strasser B, Kostner K, Dunky A, Haber P (2005) Strength and endurance training lead to different post exercise glucose profiles in diabetic participants using a continuous subcutaneous glucose monitoring system. Eur J Clin Invest 35:745-751

183. Wagner H, Degerblad M, Thorell A et al (2006) Combined treatment with exercise training and acarbose improves metabolic control and cardiovascular risk factor profile in subjects with mild type 2 diabetes. Diabetes Care 29:1471-1477

184. Schneider SH, Amorosa LF, Khachadurian AK, Ruderman NB (1984) Studies on the mechanism of improved glucose control during regular exercise in type 2 (non-insulin-dependent) diabetes. Diabetologia 26:355-360

185. Howorka K, Pumprla J, Haber P, Koller-Strametz J, Mondrzyk J, Schabmann A (1997) Effects of physical training on heart rate variability in diabetic patients with various degrees of cardiovascular autonomic neuropathy. Cardiovasc Res 34:206214

186. Farrell PA (2001) Protein metabolism and age: influence of insulin and resistance exercise. Int J Sport Nutr Exerc Metab 11(Suppl):S150-S163

187. Koopman R, Zorenc AH, Gransier RJ, Cameron-Smith D, van Loon LJ (2006) Increase in S6K1 phosphorylation in human skeletal muscle following resistance exercise occurs mainly in type II muscle fibers. Am J Physiol Endocrinol Metab 290:E1245-E1252

188. Dunstan DW, Daly RM, Owen N et al (2002) High-intensity resistance training improves glycemic control in older patients with type 2 diabetes. Diabetes Care 25:1729-1736

189. Castaneda C, Layne JE, Munoz-Orians L et al (2002) A randomized controlled trial of resistance exercise training to improve glycemic control in older adults with type 2 diabetes. Diabetes Care 25:2335-2341

190. Dela F, Mikines KJ, von Linstow M, Secher NH, Galbo H (1992) Effect of training on insulin-mediated glucose uptake in human muscle. Am J Physiol 263:E1134-E1143

191. Kahn SE, Larson VG, Beard JC et al (1990) Effect of exercise on insulin action, glucose tolerance, and insulin secretion in aging. Am J Physiol 258:E937-E943

192. Dela F, Ploug T, Handberg A et al (1994) Physical training increases muscle GLUT4 protein and mRNA in patients with NIDDM. Diabetes 43:862-865

193. Perseghin G, Price TB, Petersen KF et al (1996) Increased glucose transport-phosphorylation and muscle glycogen synthesis after exercise training in insulin-resistant subjects. N Engl J Med 335:1357-1362 
194. Rogers MA, Yamamoto C, Hagberg JM, Martin WH III, Ehsani AA, Holloszy JO (1988) Effect of $6 \mathrm{~d}$ of exercise training on responses to maximal and sub-maximal exercise in middle-aged men. Med Sci Sports Exerc 20:260-264

195. Maiorana A, O’Driscoll G, Taylor R, Green D (2003) Exercise and the nitric oxide vasodilator system. Sports Med 33:10131035

196. Segal KR, Edano A, Abalos A et al (1991) Effect of exercise training on insulin sensitivity and glucose metabolism in lean, obese, and diabetic men. J Appl Physiol 71:2402-2411

197. Bruce CR, Hawley JA (2004) Improvements in insulin resistance with aerobic exercise training: a lipocentric approach. Med Sci Sports Exerc 36:1196-1201

198. Holten MK, Zacho M, Gaster M, Juel C, Wojtaszewski JF, Dela F (2004) Strength training increases insulin-mediated glucose uptake, GLUT4 content, and insulin signaling in skeletal muscle in patients with type 2 diabetes. Diabetes 53:294-305

199. Koopman R, Manders RJ, Jonkers RA, Hul GB, Kuipers H, van Loon LJ (2006) Intramyocellular lipid and glycogen content are reduced following resistance exercise in untrained healthy males. Eur J Appl Physiol 96:525-534

200. Larsen JJ, Dela F, Madsbad S, Galbo H (1999) The effect of intense exercise on postprandial glucose homeostasis in type II diabetic patients. Diabetologia 42:1282-1292

201. Larsen JJ, Dela F, Kjaer M, Galbo H (1997) The effect of moderate exercise on postprandial glucose homeostasis in NIDDM patients. Diabetologia 40:447-453

202. Di Loreto C, Fanelli C, Lucidi P et al (2005) Make your diabetic patients walk: long-term impact of different amounts of physical activity on type 2 diabetes. Diabetes Care 28:1295-1302

203. O’Donovan G, Kearney EM, Nevill AM, Woolf-May K, Bird SR (2005) The effects of 24 weeks of moderate- or highintensity exercise on insulin resistance. Eur J Appl Physiol 95:522-528

204. Detournay B, Raccah D, Cadilhac M, Eschwege E (2005) Epidemiology and costs of diabetes treated with insulin in France. Diabetes Metab 31:3-18

205. Fang ZY, Sharman J, Prins JB, Marwick TH (2005) Determinants of exercise capacity in patients with type 2 diabetes. Diabetes Care 28:1643-1648

206. Estacio RO, Regensteiner JG, Wolfel EE, Jeffers B, Dickenson M, Schrier RW (1998) The association between diabetic complications and exercise capacity in NIDDM patients. Diabetes Care 21:291-295

207. Petrofsky JS, Stewart B, Patterson C, Cole M, Al Malty A, Lee S (2005) Cardiovascular responses and endurance during isometric exercise in patients with Type 2 diabetes compared to control subjects. Med Sci Monit 11:CR470-CR477

208. Volpato S, Blaum C, Resnick H, Ferrucci L, Fried LP, Guralnik JM (2002) Comorbidities and impairments explaining the association between diabetes and lower extremity disability: the Women's Health and Aging Study. Diabetes Care 25:678-683

209. Sayer AA, Dennison EM, Syddall HE, Gilbody HJ, Phillips DI, Cooper C (2005) Type 2 diabetes, muscle strength, and impaired physical function: the tip of the iceberg? Diabetes Care 28:2541-2542

210. Andersen H, Nielsen S, Mogensen CE, Jakobsen J (2004) Muscle strength in type 2 diabetes. Diabetes 53:1543-1548

211. Castaneda C, Janssen I (2005) Ethnic comparisons of sarcopenia and obesity in diabetes. Ethn Dis 15:664-670

212. Meyer K, Lehmann M, Sunder G, Keul J, Weidemann H (1990) Interval versus continuous exercise training after coronary bypass surgery: a comparison of training-induced acute reactions with respect to the effectiveness of the exercise methods. Clin Cardiol 13:851-861
213. Meyer K, Samek L, Schwaibold M et al (1997) Interval training in patients with severe chronic heart failure: analysis and recommendations for exercise procedures. Med Sci Sports Exerc 29:306-312

214. Festa A, Williams K, D'Agostino R Jr, Wagenknecht LE, Haffner SM (2006) The natural course of beta-cell function in nondiabetic and diabetic individuals: the Insulin Resistance Atherosclerosis Study. Diabetes 55:1114-1120

215. Camacho RC, Pencek RR, Lacy DB, James FD, Wasserman DH (2004) Suppression of endogenous glucose production by mild hyperinsulinemia during exercise is determined predominantly by portal venous insulin. Diabetes 53:285-293

216. Sigal RJ, Purdon C, Fisher SJ, Halter JB, Vranic M, Marliss EB (1994) Hyperinsulinemia prevents prolonged hyperglycemia after intense exercise in insulin-dependent diabetic subjects. J Clin Endocrinol Metab 79:1049-1057

217. Purdon C, Brousson M, Nyveen SL et al (1993) The roles of insulin and catecholamines in the glucoregulatory response during intense exercise and early recovery in insulin-dependent diabetic and control subjects. J Clin Endocrinol Metab 76:566573

218. Larsen JJ, Dela F, Madsbad S, Vibe-Petersen J, Galbo H (1999) Interaction of sulfonylureas and exercise on glucose homeostasis in type 2 diabetic patients. Diabetes Care 22:1647-1654

219. Riddle MC, McDaniel PA, Tive LA (1997) Glipizide-GITS does not increase the hypoglycemic effect of mild exercise during fasting in NIDDM. Diabetes Care 20:992-994

220. Gulve EA (2008) Exercise and glycemic control in diabetes: benefits, challenges, and adjustments to pharmacotherapy. Phys Ther 88:1297-1321

221. Galassetti P, Tate D, Neill RA, Richardson A, Leu SY, Davis SN (2006) Effect of differing antecedent hypoglycemia on counterregulatory responses to exercise in type 1 diabetes. Am J Physiol Endocrinol Metab 290:E1109-E1117

222. Davis SN, Mann S, Galassetti P et al (2000) Effects of differing durations of antecedent hypoglycemia on counterregulatory responses to subsequent hypoglycemia in normal humans. Diabetes 49:1897-1903

223. Davis SN, Mann S, Briscoe VJ, Ertl AC, Tate DB (2009) Effects of intensive therapy and antecedent hypoglycemia on counterregulatory responses to hypoglycemia in type 2 diabetes. Diabetes 58:701-709

224. Ceriello A (2009) Postprandial hyperglycemia and cardiovascular disease: is the HEART2D study the answer? Diabetes Care 32:521-522

225. Kodl CT, Seaquist ER (2008) Cognitive dysfunction and diabetes mellitus. Endocr Rev 29:494-511

226. Wessels AM, Scheltens P, Barkhof F, Heine RJ (2008) Hyperglycaemia as a determinant of cognitive decline in patients with type 1 diabetes. Eur J Pharmacol 585:88-96

227. Praet SF, Jonkers RA, Schep G et al (2008) Long-standing, insulin-treated type 2 diabetes patients with complications respond well to short-term resistance and interval exercise training. Eur J Endocrinol 158:163-172

228. Must A, Spadano J, Coakley EH, Field AE, Colditz G, Dietz WH (1999) The disease burden associated with overweight and obesity. JAMA 282:1523-1529

229. Sturmer T, Brenner H, Brenner RE, Gunther KP (2001) Noninsulin dependent diabetes mellitus (NIDDM) and patterns of osteoarthritis. The Ulm osteoarthritis study. Scand J Rheumatol 30:169-171

230. Praet SF, van Rooij ES, Wijtvliet A et al (2008) Brisk walking compared with an individualised medical fitness programme for patients with type 2 diabetes: a randomised controlled trial. Diabetologia 51:736-746 
231. Praet SF, Louwerens JW (2003) The influence of shoe design on plantar pressures in neuropathic feet. Diabetes Care 26:441-445

232. Perry JE, Ulbrecht JS, Derr JA, Cavanagh PR (1995) The use of running shoes to reduce plantar pressures in patients who have diabetes. J Bone Joint Surg Am 77:1819-1828

233. Kastenbauer T, Sokol G, Auinger M, Irsigler K (1998) Running shoes for relief of plantar pressure in diabetic patients. Diabet Med 15:518-522

234. Kanade RV, van Deursen RW, Harding K, Price P (2006) Walking performance in people with diabetic neuropathy: benefits and threats. Diabetologia 49:1747-1754

235. Dunstan DW, Vulikh E, Owen N, Jolley D, Shaw J, Zimmet P (2006) Community center-based resistance training for the maintenance of glycemic control in adults with type 2 diabetes. Diabetes Care 29:2586-2591

236. Dunstan DW, Daly RM, Owen N et al (2005) Home-based resistance training is not sufficient to maintain improved glycemic control following supervised training in older individuals with type 2 diabetes. Diabetes Care 28:3-9

237. Schneider SH, Khachadurian AK, Amorosa LF, Clemow L, Ruderman NB (1992) Ten-year experience with an exercisebased outpatient life-style modification program in the treatment of diabetes mellitus. Diabetes Care 15:1800-1810

238. Kirk A, Mutrie N, MacIntyre P, Fisher M (2004) Effects of a 12month physical activity counselling intervention on glycaemic control and on the status of cardiovascular risk factors in people with Type 2 diabetes. Diabetologia 47:821-832

239. West DS, DiLillo V, Bursac Z, Gore SA, Greene PG (2007) Motivational interviewing improves weight loss in women with type 2 diabetes. Diabetes Care 30:1081-1087

240. Tudor-Locke C, Bell RC, Myers AM et al (2004) Controlled outcome evaluation of the First Step Program: a daily physical activity intervention for individuals with type II diabetes. Int J Obes Relat Metab Disord 28:113-119

241. Kirk A, De Feo P (2007) Strategies to enhance compliance to physical activity for patients with insulin resistance. Appl Physiol Nutr Metab 32:549-556

242. Van Sluijs EM, Van Poppel MN, Twisk JW, Brug J, Van Mechelen W (2005) The positive effect on determinants of physical activity of a tailored, general practice-based physical activity intervention. Health Educ Res 20:345-356

243. Thomas N, Alder E, Leese GP (2004) Barriers to physical activity in patients with diabetes. Postgrad Med J 80:287-291

244. van Sluijs EM, van Poppel MN, Twisk JW, van Mechelen W (2006) Physical activity measurements affected participants' behavior in a randomized controlled trial. J Clin Epidemiol 59:404-411

245. Fowler-Brown A, Pignone M, Pletcher M, Tice JA, Sutton SF, Lohr KN (2004) Exercise tolerance testing to screen for coronary heart disease: a systematic review for the technical support for the U.S. Preventive Services Task Force. Ann Intern Med 140:W9-W24

246. Fang ZY, Schull-Meade R, Leano R, Mottram PM, Prins JB, Marwick TH (2005) Screening for heart disease in diabetic subjects. Am Heart J 149:349-354

247. Wackers FJ, Young LH, Inzucchi SE et al (2004) Detection of silent myocardial ischemia in asymptomatic diabetic subjects: the DIAD study. Diabetes Care 27:1954-1961

248. McAuley PA, Myers JN, Abella JP, Tan SY, Froelicher VF (2007) Exercise capacity and body mass as predictors of mortality among male veterans with type 2 diabetes. Diabetes Care 30:1539-1543

249. Faglia E, Favales F, Calia P et al (2002) Cardiac events in 735 type 2 diabetic patients who underwent screening for unknown asymptomatic coronary heart disease: 5 -year follow-up report from the Milan Study on Atherosclerosis and Diabetes (MiSAD). Diabetes Care 25:2032-2036

250. Valensi P, Paries J, Brulport-Cerisier V et al (2005) Predictive value of silent myocardial ischemia for cardiac events in diabetic patients: influence of age in a French multicenter study. Diabetes Care 28:2722-2727

251. Stevens RJ, Kothari V, Adler AI, Stratton IM (2001) The UKPDS risk engine: a model for the risk of coronary heart disease in Type II diabetes (UKPDS 56). Clin Sci (Lond) 101:671-679

252. Nesto RW, Phillips RT, Kett KG et al (1988) Angina and exertional myocardial ischemia in diabetic and nondiabetic patients: assessment by exercise thallium scintigraphy. Ann Intern Med 108:170-175

253. Nesto RW (1999) Screening for asymptomatic coronary artery disease in diabetes. Diabetes Care 22:1393-1395

254. Cosson E, Paycha F, Paries J et al (2004) Detecting silent coronary stenoses and stratifying cardiac risk in patients with diabetes: ECG stress test or exercise myocardial scintigraphy? Diabet Med 21:342-348

255. Bax JJ, Bonow RO, Tschope D, Inzucchi SE, Barrett E (2006) The potential of myocardial perfusion scintigraphy for risk stratification of asymptomatic patients with type 2 diabetes. J Am Coll Cardiol 48:754-760

256. Schmermund A, Mohlenkamp S, Berenbein S et al (2006) Population-based assessment of subclinical coronary atherosclerosis using electron-beam computed tomography. Atherosclerosis 185:177-182

257. Bacci S, Villella M, Villella A et al (2002) Screening for silent myocardial ischaemia in type 2 diabetic patients with additional atherogenic risk factors: applicability and accuracy of the exercise stress test. Eur J Endocrinol 147:649-654

258. Elhendy A, Mahoney DW, Khandheria BK, Burger K, Pellikka PA (2003) Prognostic significance of impairment of heart rate response to exercise: impact of left ventricular function and myocardial ischemia. J Am Coll Cardiol 42:823-830

259. Praet SF, van Loon LJ (2007) Optimizing the therapeutic benefits of exercise in type 2 diabetes. J Appl Physiol 103:11131120

260. Toft UN, Kristoffersen LH, Aadahl M, von Huth Smith L, Pisinger C, Jorgensen T (2007) Diet and exercise intervention in a general population-mediators of participation and adherence: the Inter99 study. Eur J Public Health 17:455-463

261. Chambliss HO (2005) Exercise duration and intensity in a weight-loss program. Clin J Sport Med 15:113-115

262. Bautista-Castano I, Molina-Cabrillana J, Montoya-Alonso JA, Serra-Majem L (2004) Variables predictive of adherence to diet and physical activity recommendations in the treatment of obesity and overweight, in a group of Spanish subjects. Int $\mathbf{J}$ Obes Relat Metab Disord 28:697-705

263. Daly J, Sindone AP, Thompson DR, Hancock K, Chang E, Davidson P (2002) Barriers to participation in and adherence to cardiac rehabilitation programs: a critical literature review. Prog Cardiovasc Nurs 17:8-17

264. Jacobs-van der Bruggen MA, Bos G, Bemelmans WJ, Hoogenveen RT, Vijgen SM, Baan CA (2007) Lifestyle interventions are cost-effective in people with different levels of diabetes risk: results from a modeling study. Diabetes Care 30:128-134

265. Bemelmans WJ, Wendel-Vos GCW, Bogers RP et al (2008) [Cost effectiveness of exercise and healthy diet counseling among people with increased risk of type II diabetes mellitus. Literature research and model simulations concerning 'de Beweegkuur']. RIVM report 260401005, RIVM Bilthoven, The Netherlands, 123 pages, downloaded on March 26th, 2009 from http://www.rivm.nl/bibliotheek/rapporten/260401005.html 
266. Roux L, Pratt M, Tengs TO et al (2008) Cost effectiveness of community-based physical activity interventions. Am J Prev Med 35:578-588

267. Gusi N, Reyes MC, Gonzalez-Guerrero JL, Herrera E, Garcia JM (2008) Cost-utility of a walking programme for moderately depressed, obese, or overweight elderly women in primary care: a randomised controlled trial. BMC Public Health $8: 231$

268. Wylie-Rosett J, Herman WH, Goldberg RB (2006) Lifestyle intervention to prevent diabetes: intensive and cost effective. Curr Opin Lipidol 17:37-44

269. Vijgen SM, Hoogendoorn M, Baan CA, de Wit GA, Limburg W, Feenstra TL (2006) Cost effectiveness of preventive interventions in type 2 diabetes mellitus: a systematic literature review. Pharmacoeconomics 24:425-441
270. Herman WH, Hoerger TJ, Brandle M et al (2005) The costeffectiveness of lifestyle modification or metformin in preventing type 2 diabetes in adults with impaired glucose tolerance. Ann Intern Med 142:323-332

271. Ryan DH, Espeland MA, Foster GD et al (2003) Look AHEAD (Action for Health in Diabetes): design and methods for a clinical trial of weight loss for the prevention of cardiovascular disease in type 2 diabetes. Control Clin Trials 24:610-628

272. Fredriksson J, Anevski D, Almgren P et al (2007) Variation in GYS1 interacts with exercise and gender to predict cardiovascular mortality. PLoS ONE 2:e285

273. De Moor MH, Posthuma D, Hottenga JJ, Willemsen G, Boomsma DI, De Geus EJ (2007) Genome-wide linkage scan for exercise participation in Dutch sibling pairs. Eur J Hum Genet $15: 1252-1259$ 